\title{
Hard clam extracts induce atypical apoptosis in human gastric cancer cells
}

\author{
EING-JU SONG ${ }^{1}$, MICHAEL W.Y. CHAN ${ }^{2}$, JYH-WEI SHIN ${ }^{3}$ and CHE-CHUN CHEN ${ }^{4}$ \\ ${ }^{1}$ Department of Bioscience Technology, Chang Jung Christian University, Tainan 71101; ${ }^{2}$ Department of Life Science, \\ Institute of Molecular Biology, National Chung Cheng University, Chiayi 62102; ${ }^{3}$ Department of Parasitology, \\ College of Medical, National Cheng Kung University, Tainan 70403; ${ }^{4}$ Department of Aquatic Biosciences, \\ National Chiayi University, Chiayi 60004, Taiwan R.O.C.
}

Received March 20, 2015; Accepted May 3, 2016

DOI: $10.3892 /$ etm.2017.4630

\begin{abstract}
Hard clams (HCs) are a nutritionally high-quality and popular seafood, and are established to be a potent antitumor food. The aim of the present study was to determine whether HC extracts induce apoptosis in the human gastric cancer cell line, AGS. In contrast with previously reported methods of extraction, crude extracts of $\mathrm{HC}$ were obtained by freezing and thawing and by a method free of hot water or organic solvents. The composition, quality and properties of the $\mathrm{HC}$ extracts were demonstrated to be stable since the extracts that were evaluated by capillary electrophoresis and HPLC analysis at different timepoints were similar. $\mathrm{HC}$ extracts also have an inhibitory effect against the survival of AGS cells. Treatment with HC extracts induced a marked sub-G1 DNA peak and reduced the expression of the anti-apoptotic genes BIRC5 and KPNA2. However, hallmarks of classical apoptosis such as DNA fragmentation and apoptotic body formation were not observed, indicating atypical apoptosis. Furthermore, it was revealed that $\mathrm{HC}$ extracts interrupted cell cycle progression in AGS cells through altered expression of six cell cycle-associated genes: CDC20, KPNA2, BIRC5, ANAPC2, CDKN1A and RB1. The present findings suggest that $\mathrm{HC}$ may contribute to a novel future anticancer agent.
\end{abstract}

Correspondence to: Dr Che-Chun Chen, Department of Aquatic Biosciences, National Chiayi University, 300 Syuefu Road, Chiayi 60004, Taiwan R.O.C.

E-mail:chencc@mail.ncyu.edu.tw

Abbreviations: HC, hard clams; taurine, 2-aminoethane-sulphonic acid; CE, capillary electrophoresis; FAA, free fatty acid; ANAPC, anaphase-promoting complex

Key words: hard clam, Meretrix lusoria, AGS human gastric cancer cells, atypical apoptosis, taurine

\section{Introduction}

Diet may have a pivotal role in oncogenesis and tumor suppression. In view of the increase in cancer mortality rates, numerous previous studies have indicated a close association between diet and cancer prevention (1-4). This is particularly true of types of cancer of the digestive tract, as certain diets such as bacon, sausage and hot dogs have been revealed to be associated with an increased risk of gastric cancer (5). The P-glycoprotein (multidrug resistance-related protein) $\mathrm{mdr}-1$ gene is expressed at high levels in normal human liver, gastrin, colon and kidney and in a number of tumors derived from these organs (6-8). Therefore, colon and gastric cancer have often acquired intrinsic drug resistance, which causes a very weak response to chemotherapy and thus an ineffective treatment (9). Gastric cancer is characterized by not only intrinsic drug resistance but also by acquired multidrug resistance, which may cause resistance to and failure in chemotherapy $(10,11)$. Therefore, the prevention of gastric cancer is important and dietary factors are also important $(12,13)$. Consequently, gastric cancer has become one of the most common causes of mortality worldwide $(14,15)$. The nutritionally high-quality seafood (licenced by the Hazard analysis and critical control points) referred to as 'hard clam' (Meretrix lusoria) is consumed regularly by Asian populations, and has been reported to possess antileukemic activity $(16,17)$. Therefore, prevention and treatment of gastric cancer via the diet is an important and challenging subject.

The freshwater clam (Corbicula fluminea) and hard clam (Meretrix spp.) are very popular in Southern Asia. The latter are more popular from a dietary perspective than freshwater clams as river pollution may contaminate the waters where freshwater clams thrive $(16,18)$. Hard clams (HCs) have now become one of the most pivotal aquatic products of marine cultivation, serving as a source of nutrition for people living in countries adjacent to the sea (19). HCs contain essential amino acids, nitrogenous compounds and other essential components such as taurine, glycogen, lipids and minerals such as calcium, phosphorous, iron and zinc (19-21). Due to its high protein and low cholesterol and salt content, this easily-digested organism is considered to be a high-quality food with regard to nutrients vital to humans $(19,21)$. Additionally, the nutrients within HCs are suggested to be beneficial for regulating physiological and 
biochemical functions of the human body, and for attenuating the progression of disease $(22,23)$. Specifically, HCs are rich in taurine (2-aminoethanesulfonic acid). This is an organic compound that is involved in neuromodulation, cholesterol metabolism, regulation of growth and development, glucose metabolism and regulation, maintenance of homeostasis, antioxidant function and protection from the harmful risks of radiation in humans $(24,25)$. Therefore, HC consumption may have a beneficial role in the normal physiological functioning of the brain, lungs, blood, heart, liver, pancreas, gall bladder, and kidneys $(24,26)$. In addition to their nutritional benefits, the production of HCs has increased due to their pharmacological value around the world, particularly in Asia. Previous rat model studies have revealed that extracts of freshwater clams reduce cholesterol levels $(16,27)$ and hepatic lipids, and ameliorate acute liver injuries induced by hemorrhaging (16).

Hot-water extracts of HCs have been established to have immune system-modulating properties (28). The muscle lysate of HCs has been revealed to include angiotensin I-converting enzyme (ACE) inhibitory peptides, which regulate blood pressure by converting angiotensin I to angiotensin II in humans. Therefore, HCs have the potential to prevent hypertension by inhibiting ACE activity (29,30). Identifying the diets with antitumor effects against gastric cancer and developing novel chemotherapeutic agents are critical endeavors for this field of study. However, previous studies concerning the cancer preventative and therapeutic effects of HCs have been scarce and basic (17).

In the present study, specific components of HCs were extracted without the use of hot water or any organic solvent, methods previously reported in a study by Pan et al (17). A novel method was required as hot water and organic solvent extraction methods may cause loss of active antitumor components $(17,31)$ that may be used in the development of supplemented food products. In this novel method, HCs are homogenized and bioactive substances are extracted with buffers containing protease inhibitors in a series of subsequently described processes. A nutritional database of the key free amino acids (FAA) in HCs was established, and the tumor-suppressive effects of $\mathrm{HC}$ extracts in four cancer cell lines were examined. Finally, the atypical apoptotic mechanisms that may be induced by $\mathrm{HC}$ extracts were investigated in AGS human gastric cancer cells.

\section{Materials and methods}

Chemicals and cell culture medium. L-15 medium was purchased from Gibco (Thermo Fisher Scientific, Inc. Waltham, MA, USA). Fetal bovine serum (FBS) and antibiotics were obtained from Hyclone (GE Healthcare Life Sciences, Logan, UT). Other chemicals and supplies were obtained from Sigma-Aldrich (Merck KGaA, Darmstadt, Germany) unless otherwise indicated.

Cell culture and determination of growth curves. Cells were maintained in L-15 medium with $10 \% \mathrm{FBS}$ at $37^{\circ} \mathrm{C}$ in a humidified $5 \% \mathrm{CO}_{2}$ atmosphere. To prevent serum-containing medium from affecting the anticancer activities of $\mathrm{HC}$ extracts, logarithmic growth phase cells to be used for experiments were maintained in an FBS-free medium for $72 \mathrm{~h}$. To determine growth curves, cells were treated with Trypan blue dye, and the cell numbers were counted using a hemocytometer under a Zeiss Axiophot light microscope.

Sample extraction. HCs were purchased from the Ni-Shiming aquaculture artificial breeding farm in Zhanghua, Taiwan. For preparation of the extracts, the HCs were sectioned and homogenized in $10 \mathrm{mM}$ Tris- $\mathrm{HCl}$ buffer solution with protease inhibitors, including aprotinin, leupeptin, pepstatin and PMSF, at $4^{\circ} \mathrm{C}$ using a blender. The crude extracts were centrifuged at $130,000 \mathrm{x} \mathrm{g}$ for $30 \mathrm{~min}$. The supernatant was then carefully collected and freeze-dried into powder form using a FD-5N EYELA freeze dryer (EYELA, Tokyo Rikakikai, Tokyo, Japan). From $500 \mathrm{~g}$ of the HCs, $5 \mathrm{~g}$ of powder was obtained, and this was stored in ice until analysis. For use, $0.5 \mathrm{~g}$ extract powder was dissolved in $10 \mathrm{ml}$ serum-free medium, filtered through a $0.45-\mathrm{nm}$ membrane filter and analyzed.

Analysis by capillary electrophoresis (CE). To confirm the stability and consistency of the extracts, the $\mathrm{HC}$ extracts were evaluated using $\mathrm{CE}$; four $\mathrm{HC}$ extracts that had been isolated at different time points were analyzed. An Agilent 2100 Bioanalyzer (Agilent Technologies, Inc., Santa Clara, CA, USA) was used with a LabChip GX (Caliper Life Sciences; Perkin Elmer, Hopkinton, MA, USA) for the analysis of proteins, according to the manufacturer's protocol. This involved combining $4 \mu \mathrm{l} \mathrm{HC}$ extract with $2 \mu \mathrm{l}$ denaturing solution in a microcentrifuge tube. Samples were then denatured in boiling water for 3-5 mins and then loaded into the protein chip. This is a microfabricated chip that is designed with microchannels to separate sample components electrophoretically. Samples were treated with a protein 200 Plus Dye concentrate fluorescent dye (Molecular Probes, Thermo Fisher Scientific, Inc.) that labels proteins. The components were detected by fluorescence and converted into gel-like images (bands) and electropherograms (peaks). Each chip contains an interconnected set of microchannels that separates proteins by size using electrophoresis. Use of this lab-on-a-chip approach eliminates handling sodium dodecyl sulfate polyacrylamide gels, staining or imaging steps. Two batches of samples were used with two repeats each for this experiment.

High-performance liquid chromatography (HPLC) analysis for FAA and stability of HC extracts. To control for consistent quality of the $\mathrm{HC}$ extracts and to determine the FAAs present, the prepared extracts were evaluated using modifications of the HPLC method as previously described by Häkkinen et al (32). All HPLC experiments on HC extracts were performed on an RP-18 column (Merck Millipore, Darmstadt, Germany) using a fluorescence detector (L-7420 UV detector; Hitachi, Ltd., Tokyo, Japan) with wavelengths at 210 and $436 \mathrm{~nm}$ for the determination of stability and composition, respectively. For the stability assay, the extracts were eluted using two buffers: A (acetonitrile) and B (30 mM citrate phosphate buffer in double-distilled water; $\mathrm{pH} 2.5$ ). These were performed using the following gradient: $100 \% \mathrm{~B}, 0 \% \mathrm{~A}$ between $0-5 \mathrm{~min}$; $20 \% \mathrm{~B}, 80 \% \mathrm{~A}$ at $5-60 \mathrm{~min}$. The flow rate was $1 \mathrm{ml} / \mathrm{min}$ at $40^{\circ} \mathrm{C}$. For the FAA estimate, the extracts were eluted using the buffers: A (4\% N',N-dimethylformamide in $30 \mathrm{mM}$ sodium acetate buffer; pH 6.4) and B (acetonitrile). 
Cell viability assay. Cytotoxicity was assessed using 3-(4, 5-dimethylthiazol)-2, 5-diphenyl-tetra-zoliumbromide (MTT) dye (Sigma-Aldrich) as previously described (33). Briefly, $2.5 \mathrm{ml}$ cell solution $\left(2.4 \times 10^{4}\right.$ cells $/ \mathrm{ml}$ in $\mathrm{L}-15$ medium $)$ was plated into 96 -well plates and incubated overnight at $37^{\circ} \mathrm{C}$ to enable attachment. The cells were then incubated at $37^{\circ} \mathrm{C}$ with a serum-free medium and different concentrations $(0.3125,0.625$, 1.25 and $2.5 \mathrm{mg} / \mathrm{ml}$ ) of $\mathrm{HC}$ extracts. After $0,12,24,48$ or $72 \mathrm{~h}$ of culture, $20 \mu \mathrm{l}$ of MTT solution $(500 \mu \mathrm{g} / \mathrm{ml})$ was added to each well and incubated for $4 \mathrm{~h}$ to generate the formazan crystals. Subsequently, the crystals were solubilized with dimethylsulfoxide. The 570-nm absorbance of the resulting colored solution was determined with a microplate reader (Dynatech Laboratories, Chantilly, VA, USA). The survival of cells was calculated by dividing the absorbance value with that of the control, and converting this to a percentage.

Hoechst 33258 and immunofluorescence staining for cytoskeleton and cell nucleus. Hoechst 33258 fluorescence labeling was used to determine chromatin condensation or nuclear fragmentation and immunofluorescence was used to analyze actin distribution. Briefly, the cells were washed twice with phosphate-buffered saline (PBS) and fixed with a 3:1 solution of methanol and acetate for $15 \mathrm{~min}$. Subsequent to rinsing in PBS, the cells were permeabilized with $0.5 \%$ Triton X-100 in PBS at room temperature for $20 \mathrm{~min}$ and incubated in a blocking buffer ( $1 \mathrm{~g}$ bovine serum albumin BSA in PBS) for $1 \mathrm{~h}$. Cells were then incubated with a mouse anti-actin monoclonal antibody (dilution, 1:400; Q-11221MP; Thermo Fisher Scientific Inc.) at $4^{\circ} \mathrm{C}$ overnight, washed again with PBS and $0.2 \%$ Tween, then incubated with the secondary antibody fluorescein-conjugated goat-anti mouse immunoglobulin $\mathrm{G}$ (dilution, 1:200) and stained with $10 \mathrm{mg} / \mathrm{ml}$ Hoechst 33258 at room temperature for $1 \mathrm{~h}$. Finally, the cells were rinsed with PBS 3-4 times and observed using epifluorescence microscopy.

Fluorescence staining with acridine orange. The cells were grown for $24 \mathrm{~h}$ on a chamber slide (Corning; Sigma-Aldrich) and treated with $0.3125,0.625,1.25$ and $2.5 \mathrm{mg} / \mathrm{ml} \mathrm{HC}$ extracts. The cells were then fixed with a 3:1 solution of methanol and acetate for 15-30 min and 1\% glacial acetic acid was added for $30 \mathrm{~min}$. The cells were stained with $0.001 \%$ acridine orange ( $0.05 \mathrm{~g}$ acridine orange powder in $50 \mathrm{ml}$ normal saline, kept away from light) for $30 \mathrm{sec}$ and were treated with $0.1 \mathrm{M} \mathrm{CaCl}_{2}$ for $2 \mathrm{~min}$. Finally, the excess acridine orange dye was removed using PBS and fluorescent micrographs were obtained using fluorescence microscopy.

Cell cycle analysis by flow cytometry. The cells were grown on a chamber slide (Corning; Sigma-Aldrich) and treated with HC extracts for 0 and $18 \mathrm{~h}$, and were then collected using trypsinization. The cells were fixed in $70 \%$ ethanol at $4{ }^{\circ} \mathrm{C}$ overnight, and centrifuged at $500 \mathrm{x}$ g for $5 \mathrm{~min}$. The cell pellets were washed with ice-cold PBS. The cells were labeled with $1 \mathrm{ml}$ propidium iodide (PI) solution (comprising $20 \mu \mathrm{g} / \mathrm{ml} \mathrm{PI,} 0.1 \%$ Triton X-100 and $0.2 \mathrm{mg} / \mathrm{ml}$ RNaseA, made up in PBS) for $30 \mathrm{~min}$ at room temperature in the dark. The cells were then assayed by flow cytometry (FACSCalibur; BD Biosciences, Franklin Lakes, NJ, USA), and >10,000 cells were counted in each sample.
Expression analysis of cell-cycle-related genes by human cell cycle Oligo GEArray. The Oligo GEArray ${ }^{\circledR}$ Human Cell Cycle Microarray (cat. no. OHS-020) profiles the expression levels of 128 important cell cycle genes, using a side-by-side hybridization experiment to determine differential gene expression. Initially, RNA was isolated and prepared from untreated or HC extract-treated AGS cells using a phenol-based method (TRIzol; 15596026; Invitrogen, Thermo Fisher Scientific, Inc.) followed by further purification with an ArrayGrade RNA isolation kit (GA-013; SA Biosciences; Qiagen Sciences, Inc., Gaithersburg, MD, USA). Purified mRNA samples were then added in $5-\mu \mathrm{g}$ aliquots to TrueLabeling primers, cRNA synthesis buffer and cDNA synthesis enzyme mix (SA Biosciences; Qiagen Sciences, Inc., Gaithersburg, MD, USA) for cDNA synthesis followed by cDNA amplification using biotinylated-dUTP, RNA polymerase buffer and RNA polymerase. The cRNA synthesis reaction and purification used an ArrayGrade cRNA cleanup kit (GA-012; SA Biosciences) to get rid of unincorporated dUTP and other reaction buffer. The purified cRNA from the experimental samples was mixed with a hybridization mixture that was prepared using GEAhyb Hybridization Solution. This reaction entailed incubation of the cRNA target hybridization mix at $60^{\circ} \mathrm{C}$ in shaking incubators overnight. Chemiluminescence detection (cat no. D-01; SA Biosciences) was performed in pre-warmed $\left(37^{\circ} \mathrm{C}\right)$ GEA blocking solution Q for 40 min to block the array reaction. This was followed by incubation with $5 \mathrm{X}$ alkaline phosphatase-conjugated streptavidin buffer at room temperature for $10 \mathrm{~min}$ with continuous but gentle agitation. The GEA blocking buffer was discarded and the array was rinsed with $3 \mathrm{ml}$ buffer $\mathrm{G}$ twice. Finally, $1 \mathrm{ml} \mathrm{CDP}$-Star chemiluminescent substrate was added, incubated for 2-5 $\mathrm{min}$ at room temperature and detected using a UV Photometer (UVP, Inc., Upland, CA, USA).

Statistical analysis. Data were analyzed with a one-way analysis of variance using SPSS 16.0 statistical analysis software (SPSS, Inc., Chicago, IL, USA). P $<0.05$ was considered to represent a statistically significant difference. Data are presented as the mean \pm standard deviation.

\section{Results}

Composition of FAAs in HCs. The FAA composition of HCs is reported in Table I. The FAA content in the HCs ranged from $2.8-297.6 \mathrm{mg} / 100 \mathrm{~g}$. Notably, the total mass of taurine was $297.6 \mathrm{mg} / 100 \mathrm{~g}$, which accounted for up to $60.7 \%$ of the total mass of FAAs, the greatest proportion of FAAs in HC extracts. Following taurine, glutamic acid was the second most prevalent FAA.

Analysis of quality control and stability of the HC extracts by capillary electrophoresis and an HPLC assay. To confirm the stability and consistency of extracts, the prepared HC extracts were evaluated by HPLC and Agilent 2100 protein capillary electrophoresis analyses. As shown in Fig. 1A, four HC extracts evaluated by capillary electrophoresis were similar, despite being isolated at different times. Furthermore, HPLC analyses of the samples selected from lanes $b$ and $c$ of Fig. 1A also indicated that these samples were similar (Fig. 1B). These 
Table I. Free amino acid contents of hard clams.

\begin{tabular}{lr}
\hline Amino acid & Content $(\mathrm{mg} / 100 \mathrm{~g})$ \\
\hline Essential and semi-essential & \\
Histidine & $2.8 \pm 0.1$ \\
Isoleucine & $12.7 \pm 3.2$ \\
Leucine & $16.2 \pm 3.4$ \\
Lysine & $5.9 \pm 0.1$ \\
Methionine & $5.0 \pm 3.4$ \\
Phenylalanine & $9.0 \pm 2.0$ \\
Threonine & $8.0 \pm 0.0$ \\
Valine & $8.9 \pm 1.5$ \\
Non-essential & \\
Alanine & $4.4 \pm 0.0$ \\
Arginine & $3.2 \pm 0.1$ \\
Aspartic acid & $20.1 \pm 0.0$ \\
Glutamic acid & $36.9 \pm 0.0$ \\
Glycine & $27.0 \pm 0.0$ \\
Proline & $10.0 \pm 2.0$ \\
Serine & $12.5 \pm 2.0$ \\
Taurine & $297.6 \pm 1.4^{\mathrm{a}}$ \\
Tyrosine & $10.2 \pm 2.2$ \\
Total & $490.4 \pm 2.1$ \\
& \\
\hline
\end{tabular}

Data represent mean \pm standard deviation. ${ }^{\text {a }}<0.05$ vs. total free amino acid content.

results indicate that the extraction methods are reliable, and that the HC extracts are highly stable.

$H C$ extracts induce cytotoxicity in AGS cells. To investigate the effect of $0.3125,0.625,1.25$ and $2.5 \mathrm{mg} / \mathrm{ml} \mathrm{HC}$ extracts on the viability of AGS cells over different time intervals, an MTT assay was performed. The results from sixteen independent experiments revealed that the $\mathrm{HC}$ extracts caused cytotoxicity in AGS cells in a time- and dose-dependent manner (Fig. 2). Treatment with HC extracts immediately decreased the survival of AGS cells up to $65 \%$, and higher concentrations of $\mathrm{HC}$ extracts demonstrated greater cytotoxicity (Fig. 2). However, over increasing treatment durations, lower concentrations of $\mathrm{HC}$ extracts were also effective in attenuating the survival of AGS cells. Subsequent to a 12-h treatment with HC extracts, the relative cell survival significantly increased suggesting that AGS cells may perform short-term repair or recovery prior to cell death. This transient cell repair or recovery is attributed to the increase in cell survival observed at the 20-h timepoint after treatment with the $\mathrm{HC}$ extracts. These results indicate that $\mathrm{HC}$ extracts inhibit cell growth or induce cell death in AGS cells by one of multiple possible mechanisms.

Morphological alterations of cells affected by HC extracts. To investigate the morphological changes in AGS cells induced by $\mathrm{HC}$ extracts, AGS cells treated with $0.3125,0.625,1.25$ and $2.5 \mathrm{mg} / \mathrm{ml}$ of $\mathrm{HC}$ extracts were examined for changes in nuclear and cytoskeletal organization using immunofluorescence. As shown in Fig. 3, HC extract-treated AGS cells demonstrated

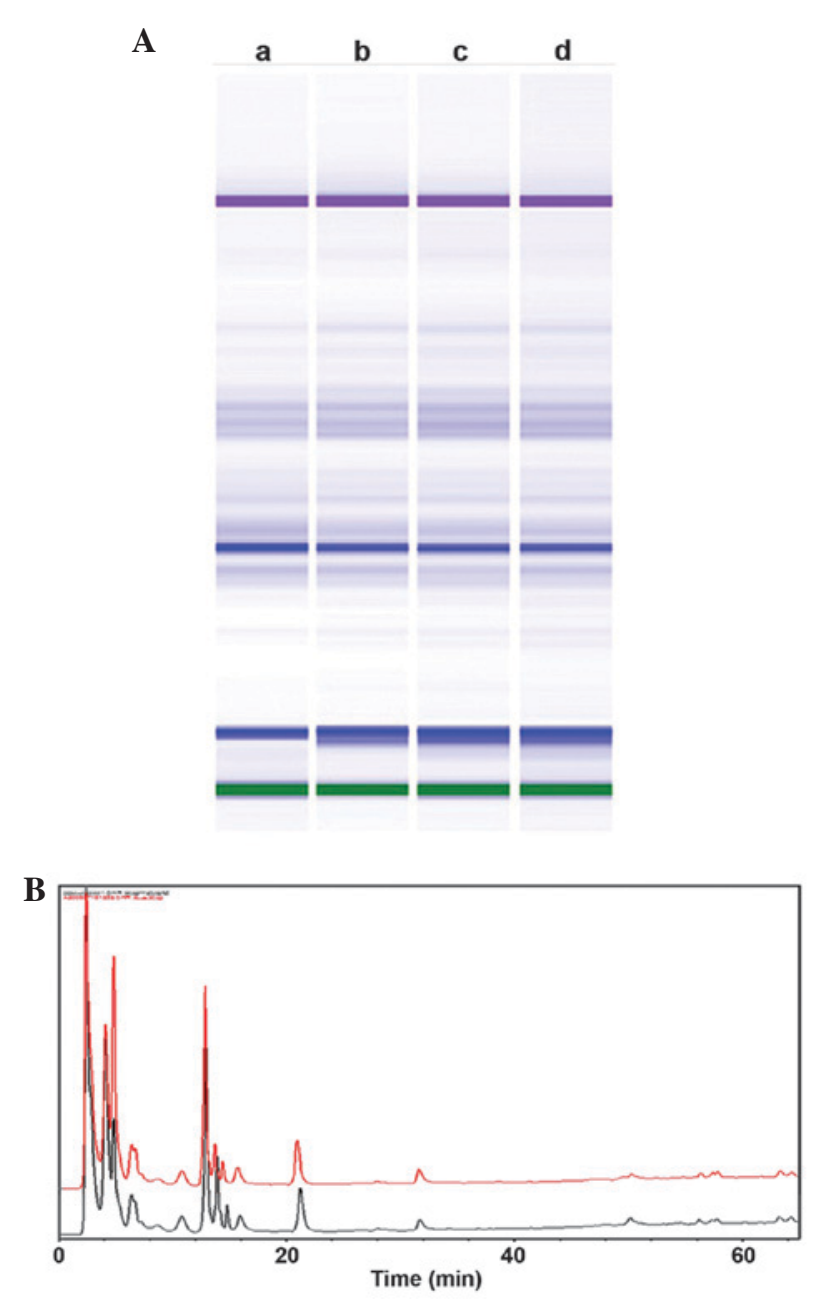

Figure 1. Stability of $\mathrm{HC}$ extracts, evaluated by $\mathrm{CE}$ using Agilent protein kits and HPLC analyses. (A) CE analysis of 2 lots of HC extracts. Lanes a and b show lot 1 and lanes $\mathrm{c}$ and $\mathrm{d}$ represent lot 2 , which were identified by the same method but at different times. (B) HPLC analysis of HC extracts. The red (A, lane b) and black (A, lane c) peaks represent samples attained independently at different times. The $\mathrm{x}$-axis represents elution time and the $\mathrm{y}$-axis indicates relative fluorescence. $\mathrm{HC}$, hard clam; CE, capillary electrophoresis; HPLC, high-performance liquid chromatography.

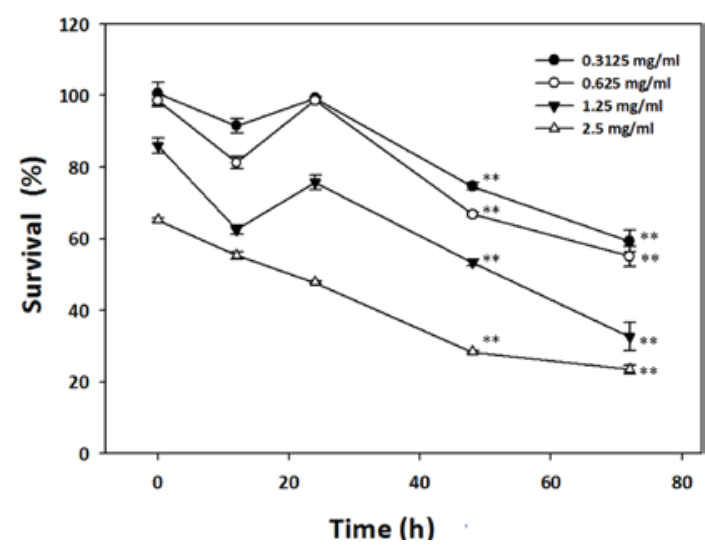

Figure 2. Dose- and time-dependent effects of $\mathrm{HC}$ extracts on viability in AGS cells, reporting cell viability following treatment with various concentrations of HC extracts $(0.3125-2.5 \mathrm{mg} / \mathrm{ml})$ for different time periods, from 0-72 h. These data indicate that HC extracts dose- and time-dependently decrease the viability of cultured AGS cells, reported as ratio to that of the untreated control cells, assessed by MTT assay. The data are presented as mean \pm standard deviation of 16 independent experiments. HC, hard clam. ${ }^{* * *} \mathrm{P}<0.05$ vs. $0 \mathrm{~h}$. 
A

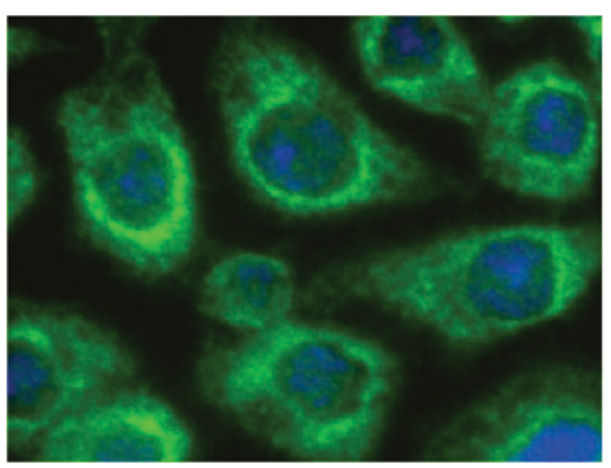

C

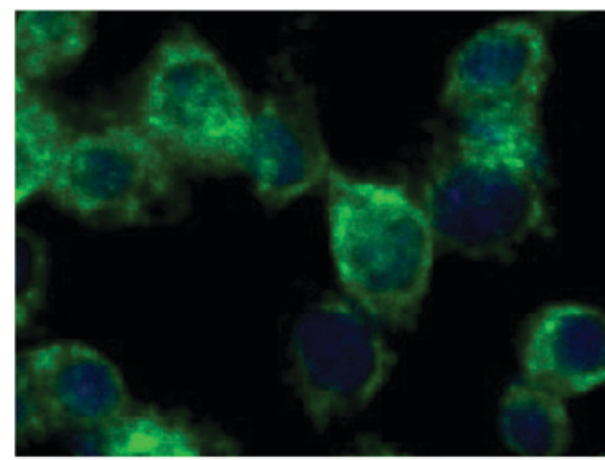

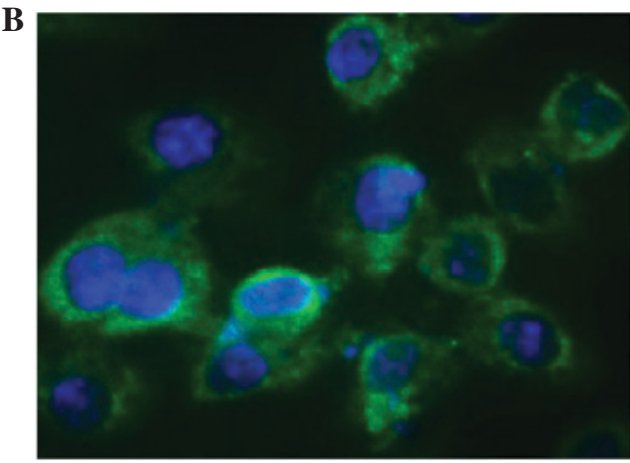

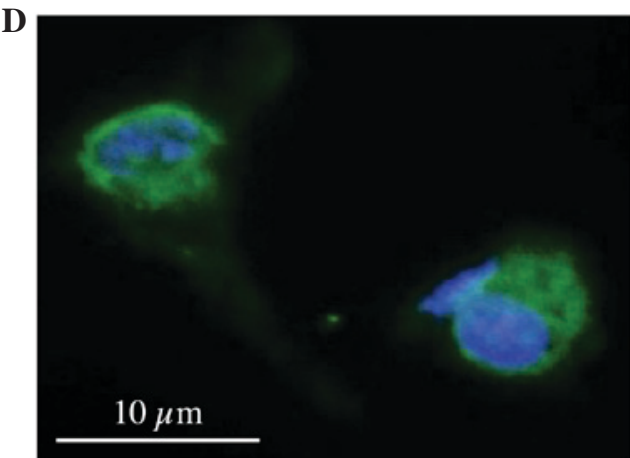

Figure 3. Alteration of actin cytoskeletal structure and changes to nuclear morphology were evaluated using epifluorescence microscopy through use of Hoechst 33342 and an anti-actin antibody. Cells were incubated with varying concentrations of hard clam extracts, as follows: (A) None, control; (B) $0.3125 \mathrm{mg} / \mathrm{ml}$; (C) $0.625 \mathrm{mg} / \mathrm{ml}$; (D) $1.25 \mathrm{mg} / \mathrm{ml}$ for $18 \mathrm{~h}$. Following staining, morphology was assessed by immunofluorescence.

A

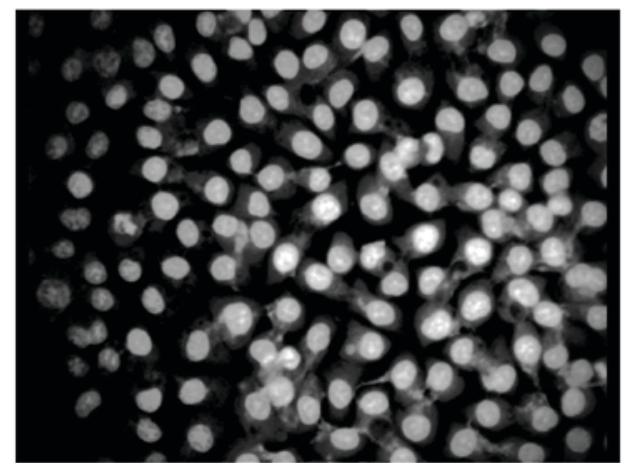

C

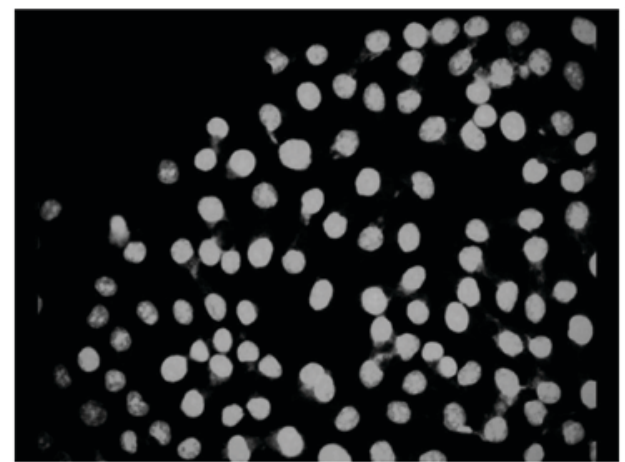

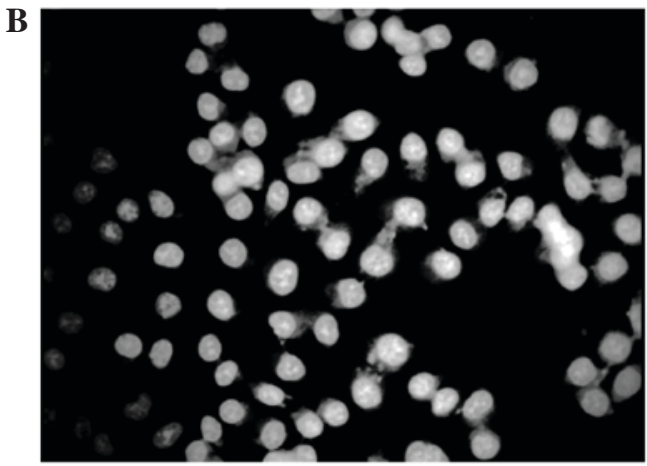

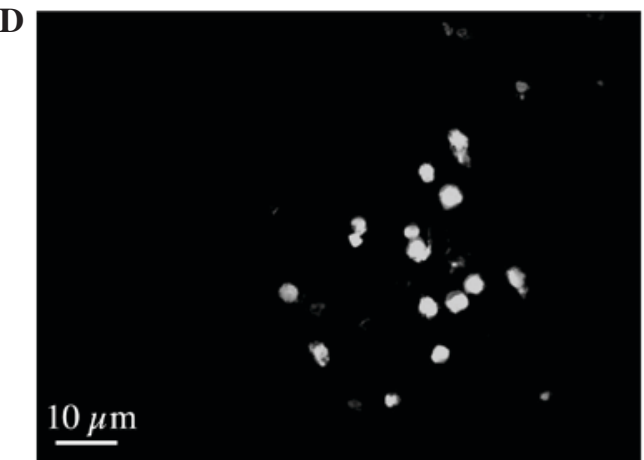

Figure 4. Chromatin condensation and morphological changes were evaluated by acridine orange stain using fluorescence microscopy. Cells were incubated with hard clam extracts as follows: (A) untreated, $0 \mathrm{~h}$; (B) $2.5 \mathrm{mg} / \mathrm{ml}, 0 \mathrm{~h}$; (C) untreated, $24 \mathrm{~h}$; and (D) $2.5 \mathrm{mg} / \mathrm{ml}, 24 \mathrm{~h}$ and then stained with acridine orange.

marked changes to their morphology, including disruption of nuclei and the cytoskeleton and cell morphological changes by actin aggregation (Fig. 3B-D), and these changes were adopted in a time- and dose-dependent manner. To further characterize the nuclear defects and the apoptotic behavior of these cells, cells were treated with $2.5 \mathrm{mg} / \mathrm{ml} \mathrm{HC}$ extracts for $24 \mathrm{~h}$ and examined by acridine orange assay. The control cells had typical cellular structures (Fig. 4A), including whole nuclei, 


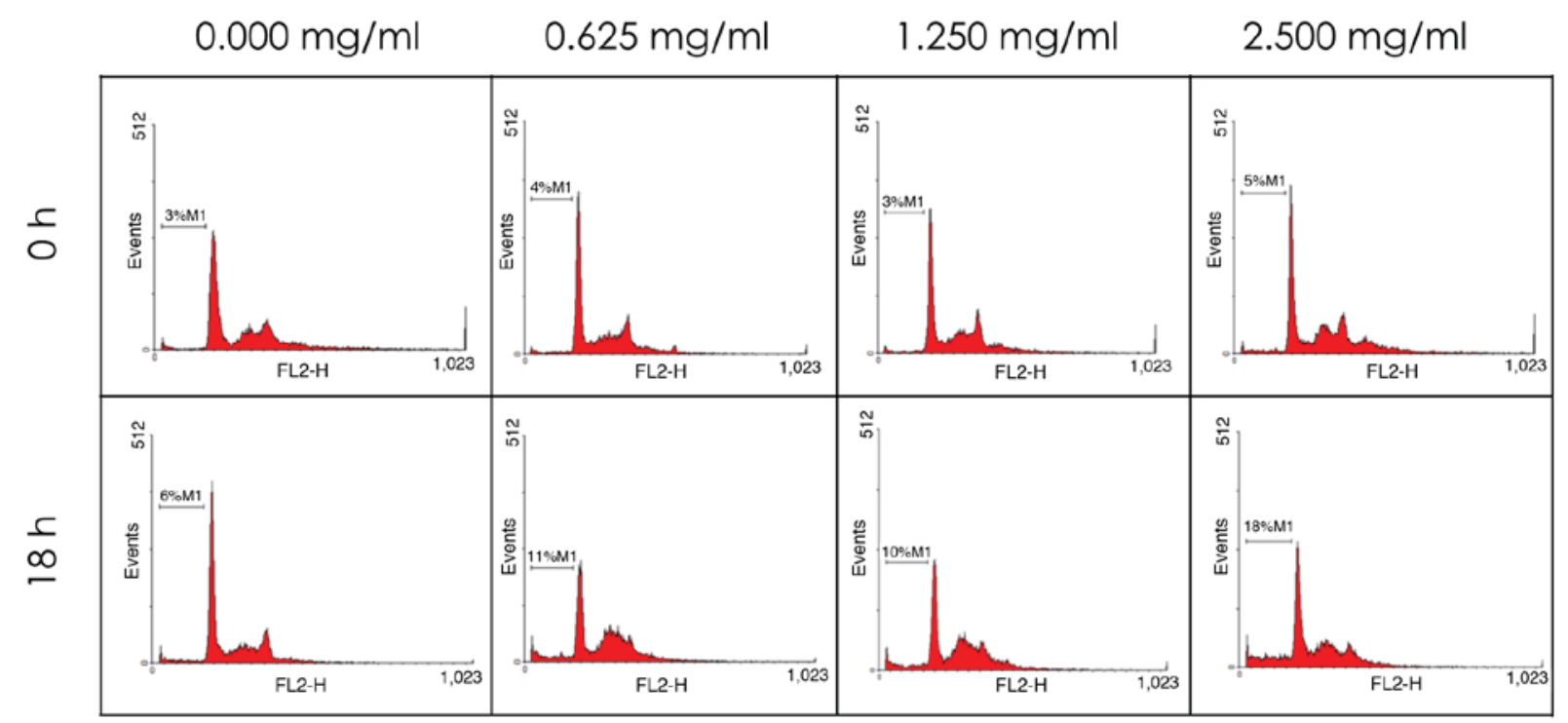

Figure 5. Dose- and time dependent effects of $\mathrm{HC}$ extracts on the cell cycle, determined by flow cytometry. Cells were cultured with $2.5,1.25 \mathrm{or} 0.625 \mathrm{mg} / \mathrm{ml}$ $\mathrm{HC}$ extracts for 0 and $18 \mathrm{~h}$. HC, hard clam.

Table II. Dose- and time-dependency effects on sub-G1 cell number, expressed as \% of total cells.

\begin{tabular}{lcc}
\hline & \multicolumn{2}{c}{ Treatment time } \\
\cline { 2 - 3 } Concentration & $0 \mathrm{~h}$ & $18 \mathrm{~h}$ \\
\hline Control & $3.00 \pm 0.00$ & $6.00 \pm 0.00$ \\
$0.625 \mathrm{mg} / \mathrm{ml}$ & $4.00 \pm 0.02$ & $11.00 \pm 0.00^{\mathrm{a}}$ \\
$1.25 \mathrm{mg} / \mathrm{ml}$ & $3.00 \pm 0.01$ & $10.00 \pm 0.01^{\mathrm{a}}$ \\
$2.5 \mathrm{mg} / \mathrm{ml}$ & $5.00 \pm 0.01^{\mathrm{b}}$ & $18.00 \pm 0.00^{\mathrm{c}}$ \\
\hline
\end{tabular}

${ }^{\mathrm{a}} \mathrm{P}<0.005 ;{ }^{\text {b }} \mathrm{P}<0.05$ and ${ }^{\mathrm{c}} \mathrm{P}<0.001$ vs. control.

clear nucleoli and uniform chromatins. Nuclei condensation was observed by incubating with different concentrations of hard clam extract, and according to the dosage (Fig. 4B-D).

Effect of HC extracts on the cell cycle in AGS cells. To investigate the mechanisms by which $\mathrm{HC}$ extracts trigger cell death, PI, a DNA chelating dye, was used to determine the DNA content and cell cycle distribution by flow cytometry. As shown in Fig. 5 and Table II, the population of sub-G1 phase cells increased in a time- and dose-dependent manner.

Detection of cell cycle-related gene expression using microarrays. The hallmarks of typical apoptosis, such as DNA fragmentation, chromatin condensation and apoptotic bodies, were not observed in the treated AGS cells. However, disruption of the nuclei and cytoskeleton, and nuclei condensation were observed by incubation with different concentrations of $\mathrm{HC}$ extract. Based on these results, it is suggested that $\mathrm{HC}$ extracts do not cause DNA fragmentation in AGS cells, but rather obstruct cell cycle progression. To determine whether genes involved in the cell cycle arrest were upregulated in AGS cells by $\mathrm{HC}$ extracts, a microarray analysis was performed.
AGS cells were treated with $\mathrm{HC}$ extracts $(0.625 \mathrm{mg} / \mathrm{ml})$ for $18 \mathrm{~h}$, and were evaluated for differential gene expression in 128 genes involved in cell cycle regulation, expression and differentiation (Table III). Compared with the control groups, this analysis revealed that the expression of six genes, CDC20, KPNA2, BIRC5, ANAPC2, CDKN1A and RB1, was affected by $\mathrm{HC}$ extracts (Fig. 6). CDC20, KPNA2 and BIRC5 were revealed to be downregulated while CDKN1A and ANAPC2 were upregulated. RB1 was not expressed in the control group, but was expressed in the experimental groups (Fig. 6).

\section{Discussion}

The present study developed a method to derive HC extracts by a method avoiding use of hot water and organic solvents. The human gastrointestinal cancer cell line AGS demonstrated a sensitivity to $\mathrm{HC}$ extracts, causing reduced viability of AGS in a dose-dependent manner. First, it was demonstrated that treatment of AGS cells with HC extracts immediately abated survival from $98 \%$ to $\sim 65 \%$ within a short period of time and continued to occur in a time- and dose-dependent manner. Following incubation with a high concentration $(2.5 \mathrm{mg} / \mathrm{ml})$ of HC extracts, the survival curve declined consistently with an increase in time, indicating that lethal cytotoxicity may be involved in the acute effects observed. By contrast, a delayed cytotoxicity was observed upon treatment with lower concentrations of HC extracts. It is possible that initially, $\mathrm{HC}$ extracts may destroy the cytotoxic effects in AGS cells, and may be associated with apoptosis. In the present study, cells began to proliferate following 12-24 h of exposure to low doses of $\mathrm{HC}$ extracts, indicating that AGS cells may undergo short-term repair or recovery prior to death, resulting in a transient increase in the survival of AGS cells. All survival curves then demonstrated similarly decreasing patterns of survival after $48 \mathrm{~h}$. Although the exact mechanism is not yet fully understood, these results may suggest that at least two major factors, including apoptosis, disruption of cell cycle progression and proliferation, are involved in the anticancer effects in AGS 


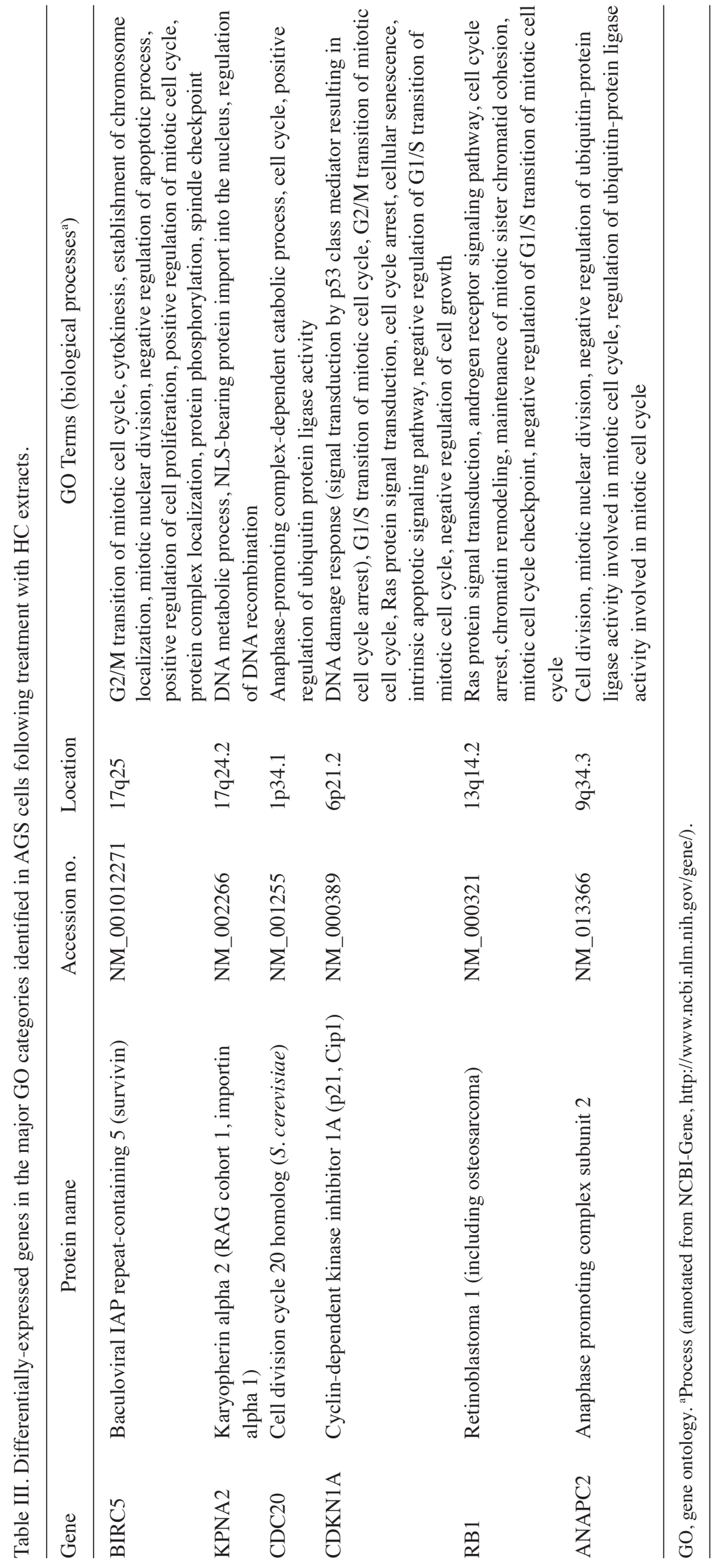




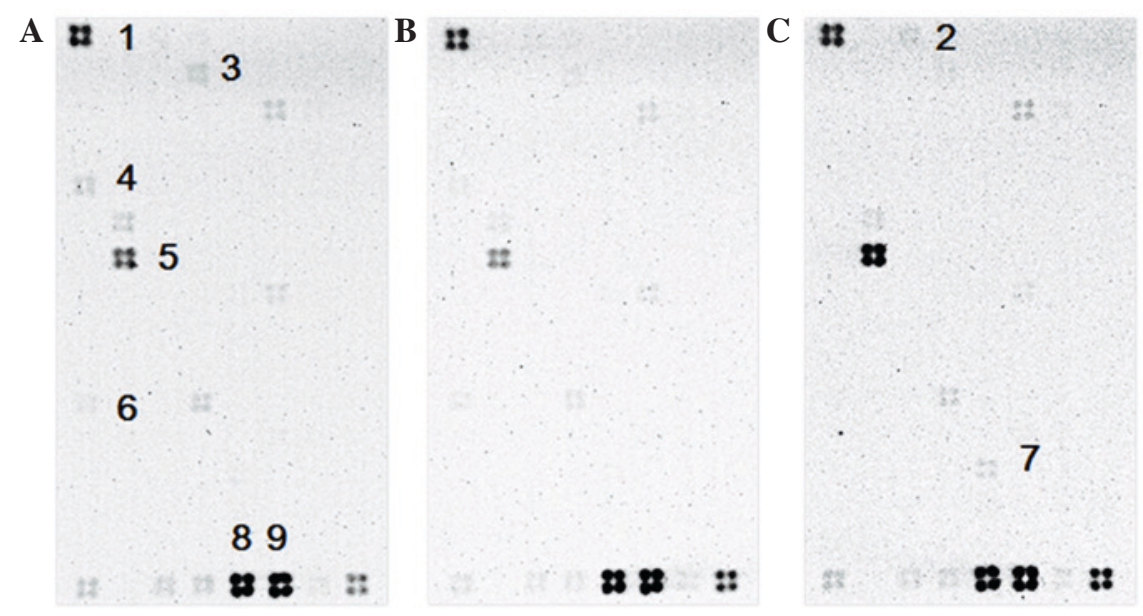

Figure 6. Microarray profiling the expression of 128 cell cycle-associated genes in untreated or HC extract-treated AGS cells. (A) AGS cells only; (B) control membrane for AGS cells incubated in Tris-HCl lysis buffer with inhibitors, including to aprotinin, leupeptin, pepstatin and PMSF; (C) experimental sample, treated with $0.625 \mathrm{mg} / \mathrm{ml} \mathrm{HC}$ extracts for $18 \mathrm{~h}$. HC, hard clam. The numbers represent the following genes: 1, RPS27A; 2, ANAPC2; 3, BIRC5; 4, CDC20; , CDKN1A; 6, KPNA2; 7, RB1; 8 and 9, ACTB (used as a control).

cells. Therefore, it may be hypothesized that HC extracts cause AGS cells to undergo apoptosis and disrupt cell cycle progression and proliferation; this is supported by evidence of atypical apoptosis and altered expression of six cell cycle-associated genes.

Apoptosis is a mechanism by which diet may prevent tumor formation $(31,34)$, and is a crucial mechanism by which $\mathrm{HC}$ extracts have previously been reported to promote HL-60 cell death in cancer (17). In the current study, HC extracts attained by different methods from the previously described approaches did not cause the hallmarks of typical apoptosis. Due to the deficiency of the DNA fragmentation (data not shown), no chromatin condensation and no apoptotic bodies were observed in treated AGS cells. In the present data, HC extracts caused an increase in the sub-G1 DNA peaks in AGS cells in a dose-dependent manner. Following exposure to a high dosage of HC extracts $(2.5 \mathrm{mg} / \mathrm{ml})$ in a continuous culture for $>2$ days, a decrease of $70 \%$ occurred in the percentage of cells. Furthermore, nuclear shrinkage, stimulation of detachment of cells during suspension growth $(35,36)$ and the downregulation of anti-apoptotic BIRC5 and KPNA2 genes in AGS cells have also been observed in this and previous studies. These are similar to the hallmarks of apoptosis (35-38). However, following prolonged treatment of the cells with $2.5 \mathrm{mg} / \mathrm{ml} \mathrm{HC}$ extracts for $24 \mathrm{~h}$, karyorrhexis and plasma membrane bursting of AGS cells were reported. Plasma membrane bursting, which may have resulted from a loss of plasma membrane integrity induced by $\mathrm{HC}$ extracts, is characteristic of atypical apoptosis (39). In summary, the present results suggest that the cytotoxicity of $\mathrm{HC}$ extracts is induced through atypical apoptosis in AGS cells. Multiple previous studies support a hypothesis of atypical apoptosis in AGS cancer cells treated with HC extracts, such as the absence of DNA fragmentation (36), loss of chromatin condensation (40) and an absence of detectable apoptotic body formation $(41,42)$.

Other possible evidence of apoptosis induced from $\mathrm{HC}$ extracts could be due to major compositions of taurine. The taurine content in the HC extracts was higher than that of any other FAAs (Table I), and this may protect the gastric mucosa from injury or oncogenesis (43). Taurine has also been reported to inhibit multiple types of tumor including hepatocellular carcinoma, head and neck carcinoma, lymphoma and colorectal carcinoma (44-46). Due to the direct damage caused to the mitochondria of cancer cells, a high concentration of taurine accumulating in cancer cells may result in apoptosis $(47,48)$. However, induction of atypical apoptosis may also occur, as demonstrated in the current study.

$\mathrm{Xu}$ et al (49) reported that simultaneous occurrence of apoptosis and perturbation of the cell cycle effectively controls cell proliferation and induces cancer cell death. Interference to the cell cycle may be caused by alterations to the distribution of cells across different stages of the cell cycle (Fig. 6) and regulation of associated genes, resulting in inhibition of cell growth and proliferation. In the present study, these cell cycle-associated genes appeared to indirectly induce death in AGS cells, mediated by HC extracts. This was demonstrated in 6 genes, subsequent to a preliminary analysis of the expression of the 128 genes of cell cycle-associated genes. The genes ANAPC2, CDKN1A, and RB1, which are associated with cell cycle arrest, tumor suppression and apoptosis, increased in expression in $\mathrm{HC}$ extract-treated AGS cancer cells. However, KPNA2, CDC20 and BIRC5, which are involved in DNA repair, cell cycle progression, anti-apoptotic activity and oncogenesis were inhibited. These results indicated the concomitant effects of interference with cell cycle progression, decreased cell growth, inhibited DNA repair and increased cell death in AGS cells. The possible effects on these six genes could also be due to the up- or downregulation of genes involved in transcription. The RB1 gene, which is a classical tumor suppressor gene and regulates the cell cycle, has been reported to transactivate the CDKN1A gene product $\mathrm{p} 21$ to induce subsequent transcription and expression (50). In the current study, it was determined that the RB1 gene was not expressed in a control group, but was expressed in the $\mathrm{HC}$ extract-treated experimental groups. Furthermore, CDKN1A and ANAPC2 expression were upregulated in $\mathrm{HC}$ extract-treated AGS cells. These data indicate that RB1, a tumor suppressor, may threaten the survival of AGS cells, and that the RB1 gene also activates CDKN1A gene expression. Consequently, these factors may induce cell 
cycle exit (51). Subsequent to treatment with HC extracts for $18 \mathrm{~h}$, an increased expression of the CDKN1A gene, which is involved in the G1/S cell cycle checkpoint, interrupted cell cycle progression by inhibiting CDK2 and CDK4, blocked DNA replication, inhibited repair by binding to proliferating cell nuclear antigen and is likely to have caused the cell cycle to be impeded at all stages of G1, S and G2/M phases (52-54). These results were similar to the downregulation of KPNA2, a DNA repair gene, observed in HC-extracted-AGS cells (52-54). Similarly, high levels of CDKN1A gene expression also inhibit the expression of BIRC5, an anti-apoptotic gene. Consequently, high levels of CDKN1A gene expression interrupt the progression at mitosis and anti-apoptotic functioning in cells (55). The products of the CDC20 gene, which suppresses p21, are activators of the anaphase-promoting complex/cyclosome (ANAPC/C) required for the metaphase-anaphase progression during mitosis (56-58). Reduction in the expression of the CDC20 gene in treated AGS cells would therefore result in interference with mitotic progression. The present study indicates that upregulation of ANAPC2, which is a subunit of the anaphase promoting complex with a function similar to that of the ANAPC gene, markedly occurs following treatment with HC extracts. The ANAPC 2 gene in treated AGS cells may have a central role in cell cycle control, tumor suppression and maintenance of the $\mathrm{G}_{0}$ phase (59-62).

The current study cannot exclude the possibility of the involvement of other factors such as oxidation $(17,34)$. However, whether or not other mechanisms are involved, the mechanism by which HC extracts cause cytotoxicity or growth inhibition in AGS cells requires additional clarification.

In conclusion, the current in vitro experimental data demonstrate that $\mathrm{HC}$ extracts induce a significant suppression of cell growth and cytotoxicity in AGS gastric cancer cells. This was revealed to involve atypical apoptosis, interfere with cell growth, inhibit DNA repair and block or slow cell cycle progression. Therefore, it is suggested that HCs may be a healthy food and may slow down the progress of tumors, serving to promote anticancer effects. HC extracts may thus have potential as a source of novel anticancer drugs.

\section{References}

1. Ferruzzi MG and Blakeslee J: Digestion, absorption, and cancer preventative activity of dietary chlorophyll derivatives. Nutr Res 27: 1-12, 2007.

2. Kelloff GJ, Boone CW, Crowell JA, Steele VE, Lubet R and Sigman CC: Chemopreventive drug development: Perspectives and progress. Cancer Epidemiol Biomarkers Prev 3: 85-98, 1994.

3. Lee HS, Na MH and Kim WK: alpha-Lipoic acid reduces matrix metalloproteinase activity in MDA-MB-231 human breast cancer cells. Nutr Res 30: 403-409, 2010.

4. Sutandyo N: Nutritional carcinogenesis. Acta Med Indones 42: $36-42,2010$.

5. Howson CP, Hiyama T and Wynder EL: The decline in gastric cancer: Epidemiology of an unplanned triumph. Epidemiol Rev 8: $1-27,1986$.

6. Suruo T: Mechanisms of multidrug resistance and implications for therapy. Jpn J Cancer Res 79: 285-296, 1988.

7. Thiebaut F, Tsuruo T, Hamada H, Gottesman MM, Pastan I and Willingham MC: Cellular localization of the multidrug- resistance gene product P-glycoprotein in normal human tissues. Proc Natl Acad Sci USA 84: 7735-7738, 1987.

8. Woolley PV III, Kumar S, Monks TF and Ortiz JE: Colon cancer as a model for resistance to antineoplastic drugs. In: Mechanisms of Drug Resistance in Neoplastic Cells. Woolley PV III and Tew KD (eds). Academic Press Inc. San Diego, CA, p3, 1988.
9. Ikeda Y, Mori M, Adachi Y, Matsushima T, Sugimachi K and Saku M: Carcinoembryonic antigen (CEA) in stage IV gastric cancer as a risk factor for liver metastasis: A univariate and multivariate analysis. J Surg Oncol 53: 235-238, 1993.

10. Song EJ, Yang VC, Chiang CD and Chao CC: Potentiation of grow th inhibition due to vincristine by ascorbic acid in a resistant human non-small cell lung cancer cell line. Eur J Pharmacol 292: 119-125, 1995.

11. Zhang D and Fan D: Multidrug resistance in gastric cancer: Recent research advances and ongoing therapeutic challenges. Expert Rev Anticancer Ther 7: 1369-1378, 2007.

12. Graham S, Haughey B, Marshall J, Brasure J, Zielezny M, Freudenheim J, West D, Nolan J and Wilkinson G: Diet in the epidemiology of gastric cancer. Nutr Cancer 13: 19-34, 1990.

13. Kono $\mathrm{S}$ and Hirohata T: Nutrition and stomach cancer. Cancer Causes Control 7: 41-55,1996.

14. Kelley JR and Duggan JM: Gastric cancer epidemiology and risk factors. J Clin Epidemiol 56: 1-9, 2003.

15. Parkin DM, Bray F, Ferlay J and Pisani P: Global cancer statistics, 2002. CA Cancer J Clin 55: 74-108, 2005.

16. Chijimatsu T, Tatsuguchi I, Oda H and Mochizuki S: A Freshwater clam (Corbicula fluminea) extract reduces cholesterol level and hepatic lipids in normal rats and xenobiotics-induced hypercholesterolemic rats. J Agric Food Chem 57: 3108-3112, 2009.

17. Pan MH, Huang YT, Ho CT, Chang CI, Hsu PC and Sun Pan B: Induction of apoptosis by Meretrix lusoria through reactive oxygen species production, glutathione depletion, and caspase activation in human leukemia cells. Life Sci 79: 1140-1152, 2006.

18. Sazimal, I and D'Angelo GB: The Asian invasive freshwater clam Corbicula fluminea as prey of two native waterbirds in SouthEastern Brazil. Folia Malacol 21: 293-295, 2013.

19. Sugita M, Nakae H, Yamamura T, Takamiya Y, Itasaka O and Hori T: The occurrence of glycosphingolipids containing mannose in the sea-water bivalve, Meretrix lusoria (Hamaguri). J Biochem 98: 27-34, 1985.

20. Karnjanapratum S, Benjakul S, Kishimura H and Tsai YH: Chemical compositions and nutritional value of Asian hard clam (Meretrix lusoria) from the coast of Andaman Sea. Food Chem 141, 4138-4145, 2013.

21. Kritchevsky D, Tepper SA, Ditullo NW and Holmes WL: The sterols of seafood. J Food Sci 32: 64-66, 1967.

22. Simopoulos AP: Omega-3 fatty acids in health and disease and in growth and development. Am J Clin Nutr 54: 438-463, 1991.

23. Sinclair AJ, Murphy KJ and Li D: Marine lipids: Overview "news insights and lipid composition of Lyprinol". Allerg Immunol (Paris) 32: 261-271, 2000.

24. Bevans CG and Harris AL: Regulation of connexin channels by $\mathrm{pH}$. Direct action of the protonated form of taurine and other aminosulfonates. J Biol Chem 274: 3711-3719, 1999.

25. Wu HC and Shiau CY: Proximate composition, free amino acids and peptides contents in commercial chicken and other meat essences. J Food Drug Anal 10: 170-177, 2002.

26. Hayes KC: Taurine requirement in primates. Nutr Rev 43: 65-70, 1985.

27. Iritani N, Fukuda E and Inoguchi K: Effect of feeding the shell fish (Corbicula japonica) on lipid metabolism in the rat. Atherosclerosis 34: 41-47, 1979.

28. Kong ZL, Chiang LC, Fang F, Shinohara K and Pan P: Immune bioactivity in shellfish toward serum-free cultured human cell lines. Biosci Biotechnol Biochem 61: 24-28, 1997.

29. Tsai JS, Chen JL and Pan BS: ACE-inhibitory peptides identified from the muscle protein hydrolysate of hard clam (Meretrix lusoria). Process Biochem 43: 743-747, 2008.

30. Wijesekara I and Kim SK: Angiotensin-I-converting enzyme (ACE) inhibitors from marine resources: Prospects in the pharmaceutical industry. Mar Drugs 8: 1080-1093, 2010.

31. Martin KR: Targeting apoptosis with dietary bioactive agents. Exp Biol Med (Maywood) 231: 117-129, 2006.

32. Häkkinen SH, Kärenlampi SO, Heinonen IM, Mykkänen HM and Törrönen AR: HPLC method for screening of flavonoids and phenolic acids in berries. J Sci Food Agric 77: 543-551, 1998.

33. Mosmann T: Rapid colorimetric assay for cellular growth and survival: Application to proliferation and cytotoxicity assays. J Immunol Methods 65: 55-63, 1983.

34. Huang YT, Huang YH, Hour TC, Pan BS, Liu YC and Pan MH: Apoptosis-inducing active components from Corbicula fluminea through activation of caspase-2 and production of reactive oxygen species in human leukemia HL-60 cells. Food Chem Toxicol 44: $1261-1272,2006$ 
35. Sun SY, Hail N Jr and Lotan R: Apoptosis as a novel target for cancer chemoprevention. J Natl Cancer Inst 96: 662-672, 2004

36. Zhang Y, Zhang QH, Wu LJ, Tashiro S, Onodera S and Ikejima T: Atypical apoptosis in L929 cells induced by evodiamine isolated from Evodia rutaecarpa. J Asian Nat Prod Res 6: 19-27, 2004.

37. Ambrosini G, Adida C and Altieri DC: A novel anti-apoptosis gene, survivin, expressed in cancer and lymphoma. Nat Med 3 : 917-921, 1997

38. Zaffaroni N, Pennati M, Colella G, Perego P, Supino R, Gatti L, Pilotti S, Zunino F and Daidone MG: Expression of the anti-apoptotic gene survivin correlates with taxol resistance in human ovarian cancer. Cell Mol Life Sci 59: 1406-1412, 2002.

39. Pozarowski P, Halicka DH and Darzynkiewicz Z: NF-kappaB inhibitor sesquiterpene parthenolide induces concurrently atypical apoptosis and cell necrosis: Difficulties in identification of dead cells in such cultures. Cytometry A 54: 118-124, 2003.

40. Hart LS, Ornelles D and Koumenis C: The adenoviral E4orf6 protein induces atypical apoptosis in response to DNA damage. J Biol Chem 282: 6061-6067, 2007.

41. Hamada M, Nishio K, Doe M, Usuki Y and Tanaka T: Farnesylpyridinium, an analog of isoprenoid farnesol, induces apoptosis but suppresses apoptotic body formation in human promyelocytic leukemia cells. FEBS Lett 514: 250-254, 2002.

42. Shiokawa D, Maruta $H$ and Tanuma S: Inhibitors of poly(ADP-ribose) polymerase suppress nuclear fragmentation and apoptotic-body formation during apoptosis in HL-60 cells. FEBS Lett 413: 99-103, 1997.

43. Son M, Kim HK, Kim WB, Yang J and Kim BK: Protective effect of taurine on indomethacin-induced gastric mucosal injury. Adv Exp Med Biol 403: 147-155, 1996.

44. Scioscia KA, Snyderman CH and Wagner R: Altered serum amino acid profiles in head and neck cancer. Nutr Cancer 30: 144-147, 1998.

45. Vecer J, Kvapil M, Sprongl L, Kubátová H, Hoch J, Jech Z and Charvát J: Tissue amino acids in patients with colorectal carcinoma. Vnitr Lek 44: 192-194, 1998 (In Czech).

46. You JS and Chang KJ: Taurine protects the liver against lipid peroxidation and membrane disintegration during rat hepatocarcinogenesis. Adv Exp Med Biol 442: 105-112, 1998.

47. Klamt $F$ and Shacter E: Taurine chloramine, an oxidant derived from neutrophils, induces apoptosis in human B lymphoma cells through mitochondrial damage. J Biol Chem 280: 21346-21352, 2005.

48. Opstad KS, Bell BA, Griffiths JR and Howe FA: Taurine: A potential marker of apoptosis in gliomas. Br J Cancer 100: 789-794, 2009
49. Xu XF, Cai BL, Guan SM, Li Y, Wu JZ, Wang Y and Liu B Baicalin induces human mucoepidermoid carcinoma Mc3 cells apoptosis in vitro and in vivo. Invest New Drugs 29: 637-645, 2011.

50. Decesse JT, Medjkane S, Datto MB and Crémisi CE: RB regulates transcription of the p21/WAF1/CIP1 gene. Oncogene 20: 962-971, 2001.

51. Carreira S, Goodall J, Aksan I, La Rocca SA, Galibert MD, Denat L, Larue L and Goding CR: Mitf cooperates with Rb1 and activates p21Cip1 expression to regulate cell cycle progression. Nature 433: 764-769, 2005.

52. Cayrol C, Knibiehler M and Ducommun B: p21 binding to PCNA causes G1 and G2 cell cycle arrest in p53-deficient cells. Oncogene 16: 311-320, 1998.

53. Harper JW, Adami GR, Wei N, Keyomarsi K and Elledge SJ: The p21 Cdk-interacting protein Cip1 is a potent inhibitor of G1 cyclin-dependent kinases. Cell 75: 805-816, 1993.

54. Padua MB and Hansen PJ: Changes in expression of cell-cycle-related genes in PC-3 prostate cancer cells caused by ovine uterine serpin. J Cell Biochem 107: 1182-1188, 2009.

55. Löhr K, Möritz C, Contente A and Dobbelstein M: p21/CDKN1A mediates negative regulation of transcription by p53. J Biol Chem 278: 32507-32516, 2003.

56. Baker DJ, Dawlaty MM, Galardy P and van Deursen JM: Mitotic regulation of the anaphase-promoting complex. Cell Mol Life Sci 64: 589-600, 2007.

57. Harper JW, Burton JL and Solomon MJ: The anaphase-promoting complex: It's not just for mitosis any more. Genes Dev 16: 2179-2206, 2002.

58. Kidokoro T, Tanikawa C, Furukawa Y, Katagiri T, Nakamura Y and Matsuda K: CDC20, a potential cancer therapeutic target, is negatively regulated by p53. Oncogene 27: 1562-1571, 2008.

59. Heilman DW, Teodoro JG and Green MR: Apoptin nucleocytoplasmic shuttling is required for cell type-specific localization, apoptosis, and recruitment of the anaphase-promoting complex/cyclosome to PML bodies. J Virol 80: 7535-7545, 2006.

60. Mo M, Fleming SB and Mercer AA: Cell cycle deregulation by a poxvirus partial mimic of anaphase-promoting complex subunit 11. Proc Natl Acad Sci USA 106: 19527-19532, 2009.

61. Morgan D, Eley L, Sayer J, Strachan T, Yates LM, Craighead AS and Goodship JA: Expression analyses and interaction with the anaphase promoting complex protein Apc2 suggest a role for inversin in primary cilia and involvement in the cell cycle. Hum Mol Genet 11: 3345-3350, 2002.

62. Wirth KG, Ricci R, Giménez-Abián JF, Taghybeeglu S, Kudo NR, Jochum W, Vasseur-Cognet M and Nasmyth K: Loss of the anaphase-promoting complex in quiescent cells causes unscheduled hepatocyte proliferation. Genes Dev 18: $88-98,2004$ 